\title{
ECONOMIA E SOCIEDADE ANTIGAS: CONCEITOS E DEBATES
}

\author{
Ciro Flamarion Santana Cardoso \\ Iniversidade Federal Fluminense
}

Résumé

Cet article critlque les conceptions qui prédominent dans les universités occidentales sur l'économle et la soclété de l'Antiquité classique de nos jours: celles d'auteurs comme M. Finley, P. Vldal-Naquet, J. -P. Vemant et M. Austin. Ces conceptions font dépendre linterprétation économique et sociale de l'Antlquité grecque et romaine des structures politiques - volre ldélogiques et meme "psychologiques" - de la clté antique. Toute autonomie est niée au niveau économique, tandis que la soclété antque est définie en tant que "soclété d'ordres", a laquelle le concept de classes sociales ne sauralt, etre étendu. Ces vues sont critiquées dans ce texte, dont l'auteur essale de montrer que les conceptions dominantes laissent de cóté d'importants aspects (tout spécialement les torces productives) d'une économie; et que le concept de classes soclales doit apres tout etre utilisé, sl on ne veut pas se limiter à envisager la société antique d'une façon seulement descriptive, acceptant sans les critjquer les vues des auteurs de l'Antiquité sur leur propre slciété. 


\section{História económica da Antiguidade Clássica}

Tomarei "Antiguidade Clássica" na sua acepção usual de História Antiga grecoromana - o que implica uma temática que se estende cronologicamente de mais ou menos 1500 a.C. até aproximadamente 500 a.D.

O problema que é preciso enfrentar desde o inf́cio consiste em saber se é ou náo possivel, como objeto de estudo minimamente viável, a História Econômica do mundo greco-romano.

Ouçamos, para começar, o que diz Anthony Snodgrass:1

"...Se fossemos capazes de fazer reviver, saindo de sua tumba, jum grego bem informado dos primeiros tempos, ele entenderia prontamente nosso desejo de descobrir coisas acerca da História Polftica de sua cultura, e poderia sem dúvida dar uma resposta a muitas de nossas perguntas. Mas logo que começássemos a perguntar-lhe sobre assuntos económicos, abrir-se-la um golfo de imcompreensão. A História Econômica $\theta$ a teorịa económica năo foram áreas de estudos para os antigos gregos (nem, aliás, para qualquer outra pessoa até o século XVIII de nossa era)."

Como Finley antes dele, ${ }^{2}$ Snodgrass não acha que tal constataçăo impeça a tentativa de escrever, hoje em dia, uma História Económica da Antiguidade: mas năo deixa de constituir uma dificuldade, além de impor como princípio, segundo acredita, a idéla de que: "Se os gregos năo separavam a atividade económica das atividades sociais $\theta$ polfticas, entåo também nâo podemos estudar isolando-a destas".3

A opiniáo de Snodgrass que acabo de cltar voltará a aparecer no debate. Mas talvez convenha perguntar antes o que se entende por economia. Moses Finley, posteriormente à constataçăo (correta) de que a Economia Polfíca surgiu, como disciplina, no século XVIII, $\theta$ a Economia tout court somente em 1890, ao escolher uma definição desse campo clentffico opta pela de Erich Roll: o problema central da pesquisa economica consistiria no estudo do "sistema económico" visto como "um enorme conglomerado de mercados interdependentes", o que transformaria o processo de troca (intercâmbio mercantil) $\theta$ a formação dos preços naquilo que os economistas devem, acima de tudo, explicar. ${ }^{4}$

Ora, creio que posso uvitar com facilidade uma confusăo pelo menos, ao declarar

1 - SNODGRASS, Anthony - Archalc Greece. The age of experiment. Londres. J.M. Dent \& Sons, 1980, p. 123.

2 - FINLEY, Moses I. - L'économie antiqua. Trad. de M.P. Higgs. Paris. Les Editions de MInuit, 1975, p. 23: "...concordu também em que tenhamos o direlto de estudar tals economias, $\theta$ de tormular sobre essas sociedades perguntas que jamais viriam ao espirito dos antigos." (Em português: A economia antiga Porto. Afrontamento, 1980.)

3 - SNODGRASS - Op. cht., p. 125.

4 - FINLEY - Op. clt. pp. 21-22 (o livro citado por Finley e: ROLL, E. - A history of economic thought Londres, 1945, p. 373). Também Snodgrass, embora trabalhando com uma definiçâo mais ampla do objeto da Economla, "escorrega" pelo caminho, caindo numa posiçăo semelhante d̀ que adotou Finley (SNODGRASS - Idem p. 127: aqui as atividades economicas sấo identificadas com a troca de mercadorias). 
liminarmente que năo me interessa trabalhar com uma visão deste tipo da ciência econômica, nem com outra, também usual, que parte da noçăo de "recursos escassos" Interessa-me a Economia Polftica tal conmo a definiu Engels: "ciencia das condiçס̋es e das formas em que as diversas sociedades humanas produziram, trocaram $\theta$ repartiram os produtos de uma maneira correspondente ${ }^{m 5}$ (estas últimas quatro palavras da definiçăo implicam que as condiçōes e formas da produçăo, troca e distribuiçáo săo intimamente ligadas entre si). Esta definiçăo, radicalmente histórica, como é óbvio năo faz da existencia de trocas e preços num mercado de tipo moderno ou capitalista (ou num conjunto de mercados interligados de tal tipo) a condiçáo sine qua non para identificar um "sistema econômico": pelo contrário, ela engloba tanto as trocas mercantis capitalistas quanto, por exemplo, as trocas de presentes entre hospedeiros $\theta$ hóspedes no mundo de Homero, ou os intercâmblos e redistribulçбes de bens e serviços efetuados por via administrativas pelo Estado faraónico no Egito antigo. Trata-se de uma diferença de intençóes $\theta$ de pontos de vista fundamental: ignorá-la seria um convite certo a um diálogo de surdos em qualquer debate.

O problema năo termina al, no entanto. Mesmo no interior do marxismo, houve quem afirmasse que a Economia Polftica tal como a definiu Engels seria possivel somente para o modo de produçăo capitalista $\theta$ impossivel de ser construida para quaisquer sociedades năo-capitalistas (e portanto, inclusive para toda História greco-romana). Escutemos a respeito a opiniáo do mexicano Raúl Olmedo: 6

"A possíbilidade de elaborar a Teoria do modo de produçăo capitalista deriva do fato fundamental seguinte: que no modo de produção capitalista a repartição do trabalho social pelos diferentes ramos da produçăo e nas proporçóes adequadas para levar a cabo a reproduçăo da sociedade em seu conjunto efetua-se de maneira automática (auto-regulada) $\theta$ independente da vontade dos sujeitos sociais. Em outras palavras, que o modo de produçăo capitalista $\theta$ o único sistema de categorias economicas cujo funcionamento 6 automático e independente da vontade dos sujeitos soclais. Este requisito nâo se dá para os modos de produçấo pré-capitallistas e pós-capitalistas".

De uma afirmaçáo de Marx - de que o aparecimento da Economia Polfica como disciplina só ocorreu sob o capitalismo - Olmedo deriva sua opinlão de que existe uma impossibilidade objetiva de elaborar teorias apllcáveis aos modos de produçáo pre-capitalistas. O Autor argumenta ainda que somente no caso do capitalismo é possivel explicar, a partir da teoria global do sistema económico, a reproduçåo da sociedade em seu conjunto. No pré-capitalismo, fatores extra-económicos - os quais năo apresentariam o caráter invariável das categorias econômicas - săo os que explicam a reproduçăo social. Assim se explicarla que os autores da Antiguidade grego-romana so puderam reflettr sobre certos fenomenos isolados que já existlam em sua época (produçáo de mercadorlas, comércio, dinheiro empréstimo a juros), mas náo produzir uma.

5. ENGELS, F El anti-Dahring. Trad. de José Verdes Montenegro y Montero. Buenos Aires. Editorial Claridad, 1970, p. 161

6 - OLMEDO, Raúl - "El estatuto teórlco de los modos de producción no capitalistas". Historia y Sociedad (México). № 5, 1975, pp. 59-64 (a chtaçăo é da página 59). 
expressão teorica do conjunto social. Somente quando as categorlas economicas se articularam ne realidade social, formando um sistema autónomo auto-regulado, póde surgir a Economla Poltica. ${ }^{7}$

Olmedo nåo prestou atençăo porém, a um elemento de peso que está presenté no texto de Marx que tomou como ponto de partida. Marx diz (o sublinhado é meu): ${ }^{8}$

"Como a Economia Polfica, tal como se manifesta historicamente, na realidade năo passa do estudo clentffico da ecomonia do período de produçăo capitallsta, năo podemos encontrar proposiçăo e teoremas a ela referentes, por exemplo, nos escritores da sociedade grega, a năo ser na medida em que certos fenomionos, como a produçáo de mercadorias, o comérclo, a moeda, o capital 0 o jưro, sâo comuns a ambas as sociedades. Mas quando os gregos tratam, ocasionalmente, desses assuntos, mostram o mesmo gênio e originalidade que em tudo mals, $\theta$ suas idélas $/ s a ̆ o$ portanto, historicamente, o ponto de partida teórico da clencla modema."

Pareco-me que o que Marx está dizendo é que: 1) a cléncia economica tal como surglu historicamente é a do capitalismo; 2) certas caracteristicas comuns à sociedade capitalista $\Theta$ a sociedade grega, ao existirem na Antiguidade, já puderam ser percebidas pelos gregos. Ocorre que, algumas dezenas de páginas antes, no mesmo livro, Engels afimava que a Economia Polltica como ciéncia da produçăo, intercâmbio e repartiçăo do produzido nas diversas sociedades humanas (o sublinhado é meu), ${ }^{9}$

"...ou seja, em toda a sua extensấo, alnda está por ser felta $O$ que possulmos até o presente em matéria de clêncla económica reduz-se, quase exclusivamente, à génese e à evoluçáo da forma de produçáo capitalista."

Pode-se constatar que as afirmaçరes de Engels e de Marx sáo equivalentes a nko supbem, absolutamente, a impossibilidade intrinseca de uma Economia Polftica "universal". Podemos apioximar o que dlz Engels de um de seus argumentos ao explcar por que Marx preferiu o "modo logico" ao "modo histórico" de exposição pàra sua critica da Economia Polftica burguesa: "faltam todos os trabalhos preparatorios" 0 que tornaria impraticável o "modo histórico" (ou forçaria Marx a escrever ele mesmo sistematicamente acerca de toda a História universal).

Náo pretendo negar que o surgimento da Economia Politica se tenha ligado, historicamente, a uma autonomia relativamente maior, nas socledades modernas, do economico na totalidade/social. Também nåo nego que o peso dos fatores extraeconomlcos na reproduçăo da sociedade global seja maior no pré-capitalismo - se bem que, como disse Plerre Vilar, a sociedade capitalista também náo possa ser pensada

7 - Idem, p. 61.

8 - ENGELS - Op. clt., pp. 242-243: sabe-se que o capftulo de onde tomel a cltaçấo fol na verdade redigido por Marx, nâo por Engels.

9 - ENGELS - Idem, p. 161.

10 - ENGELS, F. - "La Contribución a la crfica de la economla poltica de Carlos Marx", in MARX e ENGELS - Escritos económicos varlos. Trad. de W. Roces. México. Grijalbo, 1966, pp. 188-190. 
sem a cristalização pelo Direito e no Direito da propriedade privada, isto $\theta$, da apropriaçăo (usurpaçăo) da terra, dos capitais e dos bens de produçăo. ${ }^{11}$

O que estou negando é que, ao ter surgido como ciência em funçáo do capitalismo, a Economia Polltica seja inaplicável aos tipos anteriores de sociedade, produzindo teorias especfficas adequadas a eles, nas quais se leve em conta o peso da coação extra-económica e outras peculiaridades. A questăo central consiste em saber se existem ou năo, nas sociedades pré-capitalistas, regularidades estruturais passiveis de teorizaçăo. Acredito que sim, e apóio firmemente o que diz Witold Kula: ${ }^{12}$

"...para construir a teoria de uma dada categoria de fenómenos socials $\theta$ preciso que exista uma determinaçăo soclal das açoes humanas tal, que estas últimas, em sua maioria, se movam num mesmo sentido...ө sejam relteráveis, nos limites temporais e espaciais definidos, sempre que as mesmas condiçoes definidas se reproduzam.|lsto ocorre em todas as sociedades. Por conseguinte, para cada uma delas (se as fontes forem suficientes) poderemos construir uma teoria mais ou menos ampla, de conteúdo mais ou menos rico."

$O$ problema das fontes $\theta$ essencial, a ser levado em conta quando pertinente. No entanto, aqui me interessava rebater a afirmaçăo de uma impossibilidade térica, de princíplo, de uma Economia Politica do pré-capitalismo - afimaçáo cuja respeltabilidade, hoje em dia, teria de depender de uma refutaçáo dos grandes passos já dados na construçăo de uma tal disciplina por autores como Emest Labrousse, o próprio Kula $\theta$ tantos outros!

Terminando este ponto, citarel um texto de Antonio Barros de Castro que constitui a tentativa mais recente que conheço no sentido de impugnar a possibilidade de uma Economia Polfica do pré-capitalismo. No fundamental, o seu argumento consiste em afirmar que só com o capitalismo implantou-se o império das condiçóes de produçăo: ${ }^{13}$

"...A razáo|fundamental pela qual se pode pensar a época moderna através de uma obra como $O$ capital (dedicado ao estudo 'das leis naturais da produçăo' no perfodo capitalista) provém de que no capitalismo a produçáo $\theta$ a vida material em geral pissam a ser regidas por mecanismos autodeterminados e determinantes. (...)

“...Na medida em que garanta a sustentaçáo destes traços fundamentals da formaçáo social|romana - 0 ocio das classes proprietárias, 0 expansionismo milltar, bem como o páo e o circo do 'populacho' - o trabalho extraldo dos escravos é evidentemente necessário à preservaçáo deste regime social. Năo há porém como admitir que essa necessidade seja de natureza 'económica' ou, mals precisamente, que ela derive das próprlas condlçóes de produçáo."

Como se pode notar, a argumentaçáo é semelhante à de Olmedo; com uma dife-

11 - VILLAR, PierTe - Inlciación al vocabulario del analisls histórico Trad. de M. Dolors Folch. Barcelona. Critica, 1980, p. 126.

12 - KULA, Witold. Thérle économique du systeme f6odal Parls/Haia. Mouton, 1970, p. 136. (Existe em portugues.)

13 - CASTRO, António Barros de .. "A economla polfitica, o capttalismo $\theta$ a escravidăo", In LA. PA, J.R. do Amaral (compllador) - Modos de produç6o e realidade brasileira Petrópolis. Vozes, 1980 , pp. 75-77 
rença: Castro tem consciência de que sua opinião, neste ponto, é contrária à de Marx $\theta$ Engels, para os quais "năo apenas o capitalismo como também as sociedades pré-capltalistas deveriam ser estudadas a partir das condiçóes materiais da vida". ${ }^{14}$ É provável, por outro lado, que tanto Olmedo quanto Castro tenham raciocinado a partir da concepçâo restritiva atualmente vigente sobre o que é "o econômıco" concepção resultante de correntes como o marginalismo, $\theta$ também do surgimento de disciplinas especiallzadas entre as quais barreiras academicas foram elevadas (Economia, Sociologia. Demografia, Antropologia, etc.). Em contraste, na Economia Polftica marxista a concepçâo do "económico" é muito mais ampla, englobando sem dúvida alguma em sua Kglca interna, por exemplo, a estrutura $\theta$ os conflitos de classes. ${ }^{15} \mathrm{Não}$ levar isto em consideração pode conduzir a outro dlálogo de surdos, já que os participantes no debate podem nâo estar aplicando o temo "economia" às mesmas realidades.

Passando agora a uma problemática ligada ainda mais intimamente ao tema que tratamos, cumpre examinar as opinibes hoje dominantes no mundo académico a respeito da economia do mundo banhado pelo Mediterrâneo no perlodo da Antiguidade Clássica.

A primeira coisa que pode ser ressaltada é que essa imagem privilegiada - verdadeiro paradigma cientfico - insiste no carácter explicativo central que atribui à cidade-Estado (polis em grego, civitas em latim). Em termos do que agora interessa, isto signilica que a especificidade da economia clássica, definida como a economia da cidit de-Estado, surge de sua oposição à economia dos Estados e impérios do antigo Oriente Próximo, centrada nos templos e palácios. ${ }^{16}$ Um primeiro problema a este respeito é que a cidade-Estado náo fol o elemento organizador do mundo greco-romano ao longo da integralidade dos dois milénios de sua história. Pelo contrário, no conjunto dessa extensáo de tempo predominaram formas socials năo dominadas pela polis ou pela civitas: a monarquia palacial micênica, o regime discernivel na Grécia homérica, os reinos helenisticos, o Império romano, săo alguns dos casos que ilustram tal fato. Sendo assim, uma concentraçáo exclusiva da atençăo na cidade-Estado - em nome de um conjunto de concepçбes polfticas, culturais e psicologicas nela gerado $\theta$ desenvolvido $\theta$ que, afirma-se, dava sentido à Antiguldade Clássica - pode ser inadequada, se tiver a intençăo de examinar a totalldade da História Antiga da Grécia e de Roma.

Um exemplo curioso dos efeltos de uma tal opçáo é que Finley chegasse a considerar o Egito dos Ptolomeus como uma sociedade "basicamente alienlgena" (baslcally allen) em relaçấo ao "mundo grego propriamente dito" (the Greek World pro-

14 - Idem, p. 74

15 - Ver CARDOSO, Ciro F.S. a PÉREZ BRIGNOLI, Héctor - Os métodos da História Trad. de Joăo Mala. Rlo de Janeiro. Graal, 1983 (3"ed.), pp. 465-466; CARDOSO, C.F.S. ө PÉREZ BRIGNOLI, Héctor - El concepto de clases soclales Madri. Ayuso, 1977, pp. 13-14.

16 - Ct por exemplo FINLEY - Op. clt, pp. 29-39; BOGAERT, R. - "Synthese finale", in LIPINSKI, Edward (compllador) - State and temple economy in the ancient Near East 2 vols. Lovaina. Departement Orientalistiek, 1979, vol. II, pp. 745-762. 
per). ${ }^{17}$ Por este mesmo caminho, mais recente, ele eliminou de sua análise polftica do mundo clíssico - aliás magistral - toda a Histónia grega anterior e posterior ao perlodo que grosso modo se estende do século VIII ao IV a.C., e toda a História romana anterior e posterior a República (que durou aproximadamente do século $\mathrm{V}$ ao I a.C.), com o argumento de que, em sua opiniāo, a "polftica" só existiu, na Antiguidade, nos Estados em que decisóess obrigatórias eram alcançadas por discussão, argumentação e, finalmente, pelo voto (em outras palavras, em cldades-Estados). ${ }^{11}$ Comvenhamos que, assim definida, a polftica, como ele mesmo admite, foi uma das atividades mais raras em toda a História Antiga e Medieval ${ }^{19}$, o que, exatamente como no caso da economia da cidade-Estado tomacia como ponto de referência, conduz a uma reduçáo do campo de estudos inaceitável, para autores menos restritivos em seus interesses e critérios no que diz respeito ao e.studo da Antiguidade Clássica. Note-se que isto năo Implica negai a grande novidade ou a enorme importância históricas da pólis e da civitas antigas. ${ }^{20}$

Foi a partir sobretudo da década de 1960 que autores como Finley, Michael Austin, Pierre Vidal-Naquet e Jean-Plerre Vernant - entre outros - deram forma ás idélas hoje dominantes nos ambientes universitários acerca da economia do mundo grecoromano. Suas cuncepçôes surgiram em oposiçăo aos esquemas do marxismo dogmático e às opiniōes de autores como $M$. Rostovtzeff que, no final do século XIX e na primeira metade deste, exageravam muito o papel das trocas mercantis $\theta$ de supostas "burguesias urbanas" naquele mundo maciçamente rural - o qual, nos escritos desses autores, parecia excessivamente "moderno" ou mesmo "capitalista", o que constitula flagrante anacronismo. A reação a tais posiçర̋es anteriores amalgamou influências diversas: o influxo renovado das idéias de Max Weber sobre a cidade antiga, as concepçóes da Antropologia Económica de K. Polányi e seus discipulos (conhecida como "substantivista"), em certos casos a influência de um texto inédito de Marx publicado pela primeira vez somente em 1939 e difundido de fato bem mais tarde (os Grundrisse). A fusăo destas e outras influências deu-se num clima intelectual - europeu principalmente - marcado em forma crescente pela diminuiçăo do impacto do marxismo em função das sucessivas crises dos movimentos socialistas na Europa e do império cada vez maior de concepçठ丿es estruturalistas e pós-estruturalistas, adquirindo estas últimas no perfodo mais recente fortes tendências irracionalistas e intelectualmente "neoanarquistas".21

O que se afirme é, antes de mais nada, algo que remete à discussão com que começamos este capftulo: a impossibilidade de definir em forma autonoma a economia,

17 - FINLEY, M.I. - Economy and society in ancient Greece. Londres. Chatto \& Windus, 1981, p. 210.

18 - FINLEY. M.I. Politics in the ancient world Cambridge. Cambridge University Press, 1983. pp. 51 - 53. (Em portugues: Rio de Janeiro, Zahar, 1985.)

19 - Idem, p. 53.

20 - CARDOSO, C.F.S. - A cldade-Estado antiga Sâo Paulo. Ática, 1987 (2a $\theta$ d.).

21 - Ce ANDERSON, Perry - Sur le marxisme occidental Trad. de D. Letellier $\theta$ S. Niemetz. Paris, François Maspero, 1977; ANDERSON, Perry - A crise do marxisma Trad. de Denise Bottman. Sáo faulo. Brásiliense, 1984. 
o nivel económico, no relativo à Antiguidade Clássica. ${ }^{22}$ Isto porque - $\theta$ neste ponto $\theta$ manifesta a influência de Polányi -, asseguram-nos os $p$ artidários do paradigma dominante, naquele perfodo o que nós chamamos de "nivel econômico" não apenas năo era percebido como um campo unificado e coerenle pelos antigos, como também, de fato, intrinsecamente, não continha sua própria racionalidade: o que é para nós "o económico" só pode ser entendido em funçăo do social global $\theta$, mais especificamente, do nivel polftica. $A$ análise económica só teria sentido, entáo, subordinada a uma análise social com forte ênfase politica; na verdade, quase como uma espécie de subproduto desta última.

De Max Weber derivam-se idélas sobre a cidade antiga como cidade de consumidores, năo de produtores, sobre o papel da guerra, sobre o modo em que a cidadeEstado - estrutura polficica - regulava o acesso ao consumo e as niquezas entre os cidadãos $\theta$ outros membros livres da comunidade. Idéias até certo ponto similares haviam sido desenvolvidas anteriormente por Marx nos Grundrisse, mas foram conhecidas só neste século. Marx escrevera: "A história antiga clássica é história urbana, mas de cidades baseadas na propriedade da terra e na agricultura". A ligação entre economia $\theta$ cidade-Estado na Antiguidade Clássica fora fortemente ressaltada por ele: "Como resultado da concentraçáo na cidade, a comunidade como tal possul uma existência económica: ${ }^{23}$

As análises modernas que partem destas premissas - combinadas em modalidade diversas - insistem muito em negar qualquer autonomia ao nivel económico naquelas socigdades. A cidade-Estado era, diz-se, um centro de consumo que vivia numa relaçăo até certo ponto parasitária para com o campo circundante e comunidades estrangeiras exploradas. No mundo antigo, o valor de uso predominava sobre o valor de troca - isto $\theta$, a produçáo mercantil tinha fraco desenvolvimento - $\theta 0$ consumo (de homens livres) predominava sobre a produção (servil, ou seja realizada mediante o uso da escravidăo $\ni$ de outras modalidades de trabalho compulsório). Uma "politica económica" praticada pelos Estados clássicos - antes categoricamente afirmada por muitos autores - existia somente em forma extremamente limitada (como em matéria fiscal, procurando garantir o financiamento dos órgăos públicos $\theta$ da guerra através da apropriaçăo de excedentes, $\theta$ em questóes ligadas ao abastecimento de cereais e certas matérias-primas bésicas como a madeira $\theta$ os metais). Mais em detalhe, procura-se demonstrar, por exemplo, que o surgimento da moeda partiu de consideraçర̃es polfticas e náo económicas, que multas formas de troca năo podem ser definidas como verdadeiro comérclo. Ressalta-se o peso económico da guerra, definida por Aristóteles, no século IV a.C., quando travada contra os "bárbaros" (povos de língua e cultura náo-

22 - Ver por exemplo AUSTIN, M. e VIDAL-NAQUET, P. - Economies et sociétés en Gréce anclenne Paris. Armand $C$ lin, 1973, pp. 11-43. (Existe em português.) A pág. 17 1e-se: "...a ecónomia grega náo podería ser estudada de maneira correta fora do quadro da cidade-Estado."

23 - MARX, Karl - "Formas que preceden a la producción capitalista". in GODELIER, Maurice (compilador) - Antropologfa y economfa. Barcelona. Editorial Anagrama, 1976, pp. 21-46 (as citaçoes sáo da pág. 29): este cé pitulo é parte dos Grundrissa 
gregas), como sendo por natureza "um meio de aquisiçăo" (Polftica, 1256 b, 23-27); $\theta$ chama-se a atenção para a grande gravitaçăo econômica da região. ${ }^{24}$

O paradigma teórico que procurel resumir contém elementos valiosos. A critica de concepçб̋es anacrónicas, a insistência numa racionalidade social da economia no pré-capitalismo (e portanto no enorme peso, em termos económicos, de fatores que hoje em dia aparecem como extra-económicos), săo alguns desses elementos.

Năo se pode duvidar, por exemplo, de que a religlăo desempenhasse um papel muito importante nas formas de utilzaçăo da riqueza social no mundo antigo. Na Odisséia lemos, no episódio da visita de Telêmaco a Pilos, a descrição de um sacriffclo a Palas Atena (III, 418-463) ${ }^{25}$, para o qual o rei Nestor chamou um artesão a quem entregou ouro com que fosse decorado o animal a ser sacrificado (no caso, dourandose os chifres de uma novilha), em parte consumido no banquete que acompanhou a cerimónia, mas cujas coxas foram reduzidas a cinzas em honra'da deusa. Textos antigos de todas as épocas confirmam a disposiçăo dos homens da Antiguidade grego-romana no sentido de aceltar como necessánios "gastos" considerávels para garantir por melos sobrenaturais a reproduçăo da vidä social.

No entanto, a leitura dos trabalhos recentes deixa-me insatisfelto sob diversos pontos de vista.

Com frequeência, depois de afastarem as explicaçőes|anteriormente admitidas, esses textos ficam na superficie descritiva das coisas; ou descambam para posiçoes fortemente idealistas, em que a economia antiga, mais até do que da poltica, parece depender em última análise de fatores mentais - ideologicos, psicológicos -, de uma espécie de "estado de espirito" ligado à cidade-Estado e que não se explica. Muitas vezes se tem a impressão de que os autores de hoje aceitam acriticamente as opinióes dos antigos sobre si mesmos $\theta$ sua sociedade, o que $\theta$ uma atitude cientificamente inaceltável.

Finley fundamenta o seu uso do termo "economia antiga" somente 26

“...no fato de que, durante os seus últimos séculos, o mundo antigo constiula uma única entidade polftica, na existéncia de uma estrutura cultural e psicologica comum..."

Ora, isto năo me convence. Parece-me que se tem ido longe demais na minimizaçăo dos elementos proprlamente económicos. Citarel, em apoio do que estou dizendo, uma passagem do romance $O$ asno de ouro ou As metamorfoses, de Apulelo (século II d.C.). Obviamente, o que tirarmos desse texto năo pode ser generallzado para qualquer perfodo ou reglăo do antigo mundo clássico, mas isto năo é importante para o tpo de argumento que quero apresentar. o de que, em certos casos pelo menos, há aspectos da economia antiga que năo parecem explicáveis simplesmente subsumindo-os à politica e à ideologla. Por outro lado, o fato de se tratar de uma obra de ficçăo

24 - SNODGRASS - Op. cit, captulo 4; FINLEY - L'óconomie antique, capftulos 5 e 6; VEGETTI, Mario - Marxismo e società antica Milâo, Feltrinelli, 1977, pp. 9-65.

25 - HOMERO - La Odisea Trad. de L Segalá y Estalella. Móxico. Porrua, 1971, p. 25.

26 - FINLEY - L'économle antlqua, p. 39. 
năo Impugna a validade do documento, já que o Autor, nesta parte do seu livro, estava usando de um recurso bem conhecido da literatura fantástica: acumular detalhes realistas $\theta$ corriqueiros para que o leitor "acredite" na obra e termine assim por aceitar também os elementos sobrenaturais, quando finalmente fizerem sua aparlçăo. Eis aqui o trecho em questáo:27

"Chamo-me Aristomenes e sou de Aeglum; saiba também qual é a minha profissáo: ocupo-me em fomecer mel, queljo e outras mercadorias do mesmo gênero aos estalajadeiros, $\theta$ viajo em todos os sentidos através da Tessália, da Etólia, da Beocia. Assim, tendo sabido que em Hypata, a cldade mais importante de toda a Tessálla, estavam vendendo queljo fresco, de bom sabor, a um preço extremamente balxo, ful rapidamente para lá na intençâo de comprá-lo todo. Mas, como ocorre com freqüéncia, parti com o pé esquerdo e minha esperança de fazer um bom negócio se frustou, pois, na véspera, o grande mercador Lupus comprara tudo em bloco."

Esta passagem mostra sem lugar a dúvidas, para a Grécia romana do século II d.C., um sistema de comercializaçáo complexo, em vários niveis, agindo sobre um espaço considerável (Aeglum ficava perto de Corinto, Hypata muito mais ao norte). Mostra igualmente a dendencia monopolista que Aristóteles considerava "um princípio universal" da "crematistica" - palavra com treqüência traduzida para o inglés como business, mas cujo significado se aproxima mals da expressăo "busca da riqueza" (Polftica, 1259 a, 17-21). Mesmo náo sendo, como disse, genaralizável indiscriminadamente, permitte exemplificar quão inadequada pode vir a ser uma interpretaçáo da economia antiga que não leve em conta devidamente a dinâmica econômica stricto sensu.

Alguns autores que aceitam em grande medida o paradigma interpretativo atualmente vigente, dele se distanciam neste ponto pelo menos em parte. É o caso de Mario Vegetti, o qual admite que o nivel económico tende, a partir do século IV a.C., a "produzir uma dinâmica própria de funcionamento, autônoma em relaçăo aos canais polticicosociais que asseguram a reproduçáo de conjunto da socledade antiga".28 Analogamente, pesquisadores do Instituto Gramsci que se aproximam do modo dominante de pensar, por exemplo sua crtica ao "historicismo" (derlvada do estruturalismo pseudo-marxlsta de L. Althusser), desenvolvem uma análise - calcada parcialmente nos Grundrisse de Marx - que admite serem essencials os fenomenos vinculados à introduçăo (mesmo limitada e Incompleta) do capital comercial $\theta$ do capital monetárí em geral no interior da formaçâo economico-social escravista antiga, $\theta$ mais especialmente da romana. 29

A interpretaçăo hoje dominante também falha por omissâo de um fator explicativo essenclal: as forças produtivas. Nåo basta, para resolver o assunto, considerar a

27 - APULEEE - L'âne d’or ou les métamorphoses Trad. de P. Grimal Paris Gallimard, 1975, p. $34(1,5)$.

28 - VEGETTI - Op. clt, p. 57.

29 - Ct CAPOGROSSI, L, GIARDINA, A, e SCHIAVONE, A. (complladores) - Anallse marxlsta $\theta$ sociota antlcha Roma Ed. Rlunitl, 1978. 
pretensa "estagnação das técnicas" na Antiguldade Clássica (generalizaçăo das mais abusivas), logo tratando explicar tal "estagnaçáo" por fatores socials e/ou ideológicos.

O conceito de forças produtivas năo se reduz ao de técnicas de produçăo: refore-se a uma forma historicamente determinada do conjunto constituldo pelos objetos e meios de trabalho (os meibs de produçăo), mais os proprios trabalhadores vistos em suas capacidades ffsicas e mentais. As forças produtivas delimitam, em sua forte inércia (sobretudo em se tratando de sociedades pró-capitalistas), o circulo que define as permanénclas $\theta$ transformaçöes possívels numa dada formaçáo economico-social num perlodo determinado. Assim sendo, é grave constatar que a maior parte das articulaçós deste fator (tomado em todas as suas facetas) com o conjunto da Historia Económica e Social da Antiguidade está simplesmente ausente da imensa maioria das. obras recentes. ${ }^{30}$ Ora, nos casos em que tal correlaçáo fol felta em forma adequada, 0 enriqueciménto da análise es evidente. Assim ocorre quando Claude Nicolet, em parte baseando-se em P.A. Brunt, leva em conta a ligaçăo entre espaço e populaçăo como elemento explicativo - entre outros - da dinâmica da história rómana republicana; ${ }^{31}$ ou quando Bertrand Gille esclarece a formaçăo, entre o século VI e o século IV a.C., de um "sistema técnico" proprlamente grego, e mostra sua violaçăo com a história global da época (mesmo se, no fundo, em forma ainda insuficiente). ${ }^{32}$

\section{A sociedade antiga: classes ou estamentos?}

A discussão que abordaremos agora $\hat{\theta}$, sob certos aspectos, inseparável da anterior. As razóos para tratá-la à parte săo de diversos tipos: 1) didaticamente isto simplifica a exposiçáo; 2) a problemática da estrutura social da Antiguidade Clássica, se às vezes fol tratada em conjunto com as questoes económicas, em outras ocasibes deu lugar a trabalhos especfificos, alguns muito influentes: 3 ) o terceiro motivo $\theta$ de ordem pessoal: em minha opiniǎo, apesar dos problemas indicados, o paradigma dominante tem, quanto à economia antiga, multos elementos a seu favor, mas o mesmo paradigma merece-me uma apreclaçáo de conjunto bem mais negativa no concemente a suas afimaçסes sobre a natureza, o funclonamento $\theta$ os confitos das sociedades da Anttguidade Clássica.

A explicaçăo do que $\theta$, para $\mathrm{mim}$, uma visấo soclal do mundo antigo totalmente inadequada, reside em certos $\operatorname{casos}^{33}$ no fato de ter buscado sua base tebrica numa

30 - Ver CARDOSO, C.F.S. - Agrlcultura, escravidăo e capltallsmo. Petrópolis. Vozes, 1982 (29 ed.), pp. 25-31.

31 - NICOLET. Claude - Rome et la conquete du monde mediterran res de l'italle romaine. Paris. Presses Universitaires de France, 1979, pp. 75-90.

32 - GILLE, Bertand - "Le système technique des Grece", m GILLE, B. (compilador) - Histolre des techiniques. Parls. Gallmard, 1978, pp.287-374; GILLE, Bertrand - Les mécanlciens grecs Parls. Les Éditions de Minulth 1980.

33 - Por exemplo muitos dos trabalhos incluldos em: NICOLET, C. et alli - Recherches 8ur les structures sochales dans I'Antiquité classiqua Paris. Editions du Centro National de la Recherche Scientifique, 1970. 
"Sociologia histórica" falida. ${ }^{34} \mathrm{Em}$ todos os casos, parte da explicaçăo reside na tendéncia já apontada antes a aceitar acriticamente a visăo dos antigos sobre si mesmos como correspondendo à sua realidade social, com o qual se substitui a verdadeira tentativa de explicaçăo histórica por uma mera descriçăo, mesmo que se tente apresentá-la como se explicação fosse - tendéncia à qual o medo de cometer o pecado do anacronismo empurra numerosos historiadores.

Também quanto ao tema que nos ocupa agora, um dos pontos de partida na constituiçăo da interpretaçăo hoje dominante fol a insatisfaçăo com um marxismo excessivamente simplificado ou deformado, em que a "luta de classes", Inadequadamente enfocada, aparecla como um deus ex machina da Historia. Para dar um exemplo concreto, o último capftulo da História de Roma do soviético S. I. Kovaliov, intitulado "Fim do Império Romano do Ocidente. Revoluçăo dos escravos e invasăo dos bárbaros", apresenta-nos, em certo momento, uma "última fase da revolução dos escravos" antigos em que tạ revoluçăo se vinculou estreitamente aos movimentos de outras categorias oprimidas, formando uma "frente revolucionária" no interior do Império, à qual se velo juntar depols uma externa (os bárbaros), entrando ambas em contacto $\theta$ agindo em conjunto a partir do século IV d.C., o que acabou levando à queda do Império do Ocidente. ${ }^{35}$ Uma análise como esta é, sem dúvida, risivel. Náo fica melhor na versão modemizada de Plerre Dockès, que apesar de criticas ao "economicismo" $\theta$ ao "mecanicismo" que rescendem a Althusser e seus disclpulos, termina atribuindo por sua vez, em última análise, a destruiçáo do sistema escravista ao "combate clandestino" e à "guerra sociar" - as "hutas dos escravos" -, no contexto da ruina do Estado imperial romano em conseqüencia de um processo de concentraçáo de terras $\theta$ de paupertzaçăo. ${ }^{36}$.

Entretanto, o que se quis colocar no lugar de análises como estas fol um conjunto de opinibes igualmente lamentável por sua assustadora indigêncla. Afirma-se a impossibilidade de aplicar à sociedade antiga o conceito de classes sociais, preferindo-se ver tal sociedade como constitulda de estamentos, isto $\theta$, grupos de funcionamento jurfdico-politico e ideológico (ou mesmo "psicológico") e năo econômico, apoiados em opósiçốs de status (cidadăo/năo-cidadåo, livres/escravos, proprietánios/năo-proprietáros, credores/devedores - quando não jovens/adultos ou mesmo homens/mulheres... ${ }^{37}$ ). Como a economia, diz-se que tamberm à estrutura social tinha sua base na cidade-Estado. Os antagonismos sociais existentes ligavam-se em especial ás questőes em torno do poder polltico, da terra $\theta$ das dividas: mas se tratava sempre de embates entre estamentos, em intima vinculaçáo com a estruturap olfitica do Estado. Tais con-

34 - A de: MOUSNIER, Roland - As hierarqulas socials. Trad. de Miguel S. Pereira. Lisboa. Publicaços Europa-América, 1974. Mas consulte-se sobretudo a crtica demolidora e irespondivel: ARRIAZA, Amand - "Mousnier and Barber. the theortical underpining of the 'society of orders' in Early Modern Europe". Past and Present 89, novembro de 1980, pp. 39-57.

35 - KOVALIOV, S. I. - História de Roma III. El império. Trad de M. Ravonl. Buenos Aires. Ed. Futuro, 1959, pp. 290-305.

36 - DOCKES, Plerre - La liberátion médiévale. Paris. Flamarion, 1979.

37 - Ver AUSTIN e VIDAL-NAQUET - Op. cit., pp. 34-43. 
tradiçర̋es năo eram antagônicas ou "dialéticas" no sentido marxista, $\theta$ por isto só fizeram repetir-se ciclicamente ao longo da história clássica, sem desembocar em qualquer evoluçăo em direçăo a um novo tipo de sociedade.

Nota-se que, neste campo de estudos, há diferenças consideráveis entre os autores que seguem o paradigma dominante: se em Vidar-Naquet e Vemant, por exemplo. alguma influência marxista ainda $\theta$ visivel, Finley, com sua concepçăo da sociedade antiga como um continuum, um espectro ou gradaçăo de status ou posiçoses entre dols pólos - o escravo visto exclusivamente como propriedade e o homem perfeitamente livre - que săo abstraçőes hipotéticas sem existêncla reali38, na pratica, mesmo se náo o diz com clareza, tem uma base tebrica que é sobretudo weberiana. Por tal razáo ele pode, ao mesmo tempo, reconhecer sem diffculdade, e mesmo com argumentos interessantes $\theta$ pertinentes a favor de tal idéla, o caráter escravista da sociedade antiga em certas áreas centrais (Grécia, Itália peninsular, Siclia), ${ }^{39}$ e retirar de tal constataçấo a possibilidade de fundamentar uma análise de conjunto da sociedade clássica em termos de classes.

Deve-se talvez, neste ponto, levantar uma questão importante: o recuo das interpretaçóes das sociedades antigas como sociedades de classes năo se liga unicamente ao uso inadequado de tal concelto no passado; nem se deve so a razoes polticas $\theta$ ideológicas. ${ }^{40}$ Terá sido ainda mais influente nesse sentido a presença, no seio do pensamento marxista - desde o próprio Marx - de uma dicotomla teorica no emprego do concelto, o que terminou levando a uma cisáo entre os que so aceltam falar de classes quando se puder detectar uma clara conciência de classes e lutas de caráter polftico entre as classes (presença de "classes para si" formando um sistema antagónico) $\theta$ outros que seguem Marx e Engels num emprego mais geral do concelto (constataçăo da existêncla de "classes em si" ou deteminadas economicamente). Na primeira opçáo, no pré-capttalismo unicamente as classes dominantes chegaram a adquirir consciéncia, o que faz com que só sob o capltalismo contemporaneo encontremos sistemas de classes antagónicas em que tamberm as classes dominantes possam desenvolver uma consciencia adequada a seus interesses classistas. Na segunda opçăo. năo haveria inconveniente em estender a análise das classes a toda a história humana pós-tribal, embora admitindo-se considerávels especificidades aos sistemas pré-capltalistas de classes. 41

Outro fator de peso deve ter sido a dificuldade da tarefa. Mesmo os que aceltam ser possivel a análise em termos de classes das sociedades pré-capitallstas pos-titbais - com o é minha ophilăo -, obviamente nấo encontrarăo nos documentos de época a consciêncla de sua existência (já que ela só surglu a partir do século XVIII d.C.). Se-

38 - FINLEY - L'économie antique, pp. 84-86.

39 - FINLEY.M. I. - Anclent slavery and modern ideology. Nova lorque. The Viking Press. 1980, pp. 79-81.

40 - STE. CROIX, G.E.M. de - The class struggle In the anclent Greek world Londres. Duckworth, 1981, pp. 45-46, 57.

41 - CARDOSO e PÉREZ-BRIGNOLI - El concepto.... pp. 107-126. 
gundo G. Lukács, nas sociedades pré-capitalistas as classes sociais "só podem ser identificadas por meio da interpretaçăo da história" imediatamente dada, enquanto no capitalismo as classes "săo a própria realidade histórica imediatamente dada" Isto porque, nas sociedades pré-capitalistas, as categorias económicas e extra-económicas apareciam inextricavelmente entrelaçadas. ${ }^{42}$ As dificuldades que isto acarreta para historiador já haviam sido reconhecidas por Engels: ${ }^{43}$

“...enquanto em todos os perfodos anteriores a pesquisa destas causas propulsoras da historia era pouco menios do que impossivel - devido a ser tão complexa $\theta$ velada a vinculaçăo daquelas causas com seus efeltos -, na atualidade esta vinculaçăo já esta suficientemente simplificada para que o enigma possa ser decifrado."

Como ó Obvio, na Antiguidade existiram sem dúvida estamentos juridicamente fundamentados - por exemplo a "ordem senatorial" e a "ordem eqüestre" no Alto Imperio Romano. Nâo se trata pois, para os que advogam a interpretação em termos da classes e suas lutas, de negar sua existência ou abandonar seu estudo: é preciso, pelo contrário, integrá-los à análise e explicá-los. ${ }^{44}$

Uma solução concillatória pode ser encontrada em certos escritos de Maurice Godelier. Com base em alguns dos textos de Marx, pretende que, para o fundador do maxxismo, os estamentos $(\theta$, em sociedades que não sáo da alçada deste texto, as castas) acupam o mesmo lugar teorico, no pré-capitalismo, que corresponde as classes no mundo contemporâneo. Marx teria pretendido, ao chamar em certas obras às vezes estamentos $\theta$ ás vezes classes aos mesmos grupos, referindo-se a épocas pré-capitalistas, distanciar-se da interpretaçåo corrente, idealista, desses grupos, mostrando que tais estamentos envolviam relaçôes de opressão e exploraçăo, năo tendo um fundamento exclusivamente ideológico e polftico, mas pelo contrário estando tamberm ligados a uma data base económica que correspondia em cada caso a um determinado grau $\theta$ a determinadas formas de desenvolvimento das forças produtivas. ${ }^{45}$

Outros autores se puseram mais taxativamente contra a tendencla hoje dominante. O esforço mals considerável foi o de G.E.M. de Ste. Croix - o qual insiste sobre o concelto de exploraçáo na definiçăo das classes e suas lutas, mais do que propriamente sobre o de relaçós de produçăo -, que apesar de certas debilidades tem uma considerável importância teórica e historiográfica, além do grande mérto de reunir a documentação disponivel. ${ }^{46}$

O debate favortto no campo da História Social fol acerca de serem ou náo os escravos antigos uma classe social. Plerre Vidat-Naquet, tratando deste tema para o caso 1969, p. 63.

42 - LUKACS, 'G. - Historla y conciencla de clase. Trad. de M. Sacristán. México. Grijalbo,

43 - ENGELS, F. - "Ludwig Feuerbach y el fin de la filosoffa clásica alemana", In MARX e ENGELS - Obras escogidas on dos tomos Moscou. Ed. Progreso, 1971, tomo Il, p. 391.

44 - Ver STAVENHAGEN, Rodolfo - Les classes soclales dans les sociétés agraires Parls. Anthropos, 1969, pp. 23-52.

45 - GODELIER, Maurlce - L'Idéol et le matórlel. Paris. Fayard, 1984, pp. 295-329.

46 - STE. CROIX - Op. clt. 
da sociedade grega, chega a uma resposta negativa. Reconhece que, nas sociedades helênicas efetivamente escravistas, a oposiçăo entre senhores e escravos era "a contradição fundamental do mundo antigo" mas afirma também que "em nenhum momento estes senhores e estes escravos se defrontaram diretamente na prática social corrente" ${ }^{47}$ Opinião diferente foi exposta por exemplo por u. Annequim, M. Claval-Lévêque e F. Favory. $O$ fato de serem os escravos sem dúvida, em primeira aproximaçăo, uma categoria jurfdica, náo deve impedir que nos interroguemos igualmente acerca do papel desempenhado por certos escravos, em certos perfodos $\theta$ em certas regibes, nas re laçós de produçăo fundamentals, sem perder de vista as especificidades estruturais da sociedades antigas (incluindo o peso dos fatores extra-económicos, da coaçăo extra-económica, na determinaçăo e na reproduçăo da exploraçăo social). Isto permitiria, apesar de grande disparidade de funçסes que pessoas escravizadas podiam desempenhar, que fosse reconhecido o carácter de classe de certos conjuntos de escravos antigos. Estes autores também acham que $\theta$ preciso assumir uma posiçăo mais nuançada, ao examinar a questăo da conciência $\theta$ da luta de classes, do que a que foi assumida taxativamente por Vidal-Naquet ${ }^{48}$

Embora o problema asteja longe de uma solução, pendo mais para uma posição como a destes Autores do que para a de Vidal-Naquet, na qual percebo uma projeçăo. em direção ao passado, dos conceltos de classes e luta de classes tais como podem ser definidas sob o capitalisma, concluindo, ao nåo os identificar em tal forma na sociedade grega, que esta última năo conheceu as classes e suas lutas em quaisquer formas. Também me parece que a objeçăo de terem os escravos status varlados do ponto de vista económico-social, em que insiste Finley ${ }^{49}$, $\theta$ fútil. No século I d.C., um escravo imperial encarregado de funçठes administrativas no governo central do imperio Romano, ou um escravo a quem o seu senhor consentiu um pecúllo importante (que podia incluir outros escravos), por um lado, e um escravo rural encerrado à nolte num cárcere privado ou ergastulum, por outro lado, representavam sem dúvida realidades soclals heterogêneas. Mas quantos eram os escravos das primeiras categorlas menclonadas, e quantos os da última? Năo sabemos, por náo se terem conservado dados numéricos suficientes para esclarecer a questáo apresentando clfras; mas as fontes dlsponivels sâo mals do que suficlentes para afirmar com certeza absoluta que os escravos empregados como máo-de-obra duramente explorada em minas, propriedades rurais $\theta$ outras atividades produtivas, embora multo menos visivels para nós como individuos (por náo terem a oportunidade de delxar rastro indlvidual nos tpos de fontes gerados por aquela sociedade), eram mult'ssimo mais numerosos - $\theta$ multo mals e8senclals para o funcionamento da sociedade da época - do que os escravos social $\theta$ economicamente privileglados.

47 - VIDAL-NAQUET, Plerre - "Les esclaves étalent-lis une classe?". In Formas de exploraçáo do trabalho e relaçoes socials na Antiguidade clássica Trad. de M. da Luz Veloso. LisDoa. Ed. Estampa, 1978, pp.33-39.

48 - ANNEQUIN, J., CLAVAL-LEVÉQUE, M e FAVOR, F. - "Apresentaçăo". In Formas de esploraçáo do trabalho e relaçరes socials na Antiguldade clássica. Trad. de M. da Luz Veloso. Lisboa. Ed. Estampa, 1978, pp. 33-39.

49 - FINLEY - L'économle antlque, captulo 3. 